\title{
Overexpression of stress-related genes in Cuscuta campestris in response to host defense reactions
}

\author{
HAMed Rezaei ${ }^{1}$, Khalil Alamisaeed ${ }^{1 *}$, Cobra Moslemkhani ${ }^{2}$ \\ ${ }^{1}$ Agriculture and Natural Resources University of Ramin, Ahvaz, Iran \\ ${ }^{2}$ Seed and Plant Certification and Registration Institute. \\ Agricultural Research, Education and Extension Organization (AREEO), Teheran, Iran
}

\begin{abstract}
Herb dodder (Cuscuta spp.) is one of the most important parasitic plants that can severely affect crop yields in the world. So far, interactions of this parasitic plant with hosts were not investigated adequately. Here, we conducted a differential expression analyzes and identified a number of genes that were differentially expressed in haustorium tissue compared with the stem of Cuscuta campestris growing on Alfalfa. We obtained $439 \mathrm{cDNA}$ fragments from haustoria (parasite-host connection zone) and stems (25 cm away from connections zones) using the cDNA-AFLP (Amplified Fragment Length Polymorphism) method with eight different primer combinations. Of 439 transcript-derived fragments (TDFs) that were detected, 145 fragments were identified as differentially expressed genes. Five TDF sequences were similar to known functional genes involved in signal transduction, metabolism, respiration, and stress responses. Genes encoding DEAD-box ATP-dependent RNA helicase, potential heme-binding protein, lysine-specific demethylase 5A were selected for qRT-PCR. The qRT-PCR analyzes confirmed the results obtained using cDNA-AFLP. Our findings shed light on the elicitation of dodder defense responses in the connection zone to overcome plant defense reactions.
\end{abstract}

Key words: Cuscuta campestris, cDNA-AFLP, haustorium, Alfalfa

\section{Introduction}

The genus Cuscuta, commonly named dodder, includes 170 parasitic species that are distributed throughout the world (Holm et al., 1997). Cuscuta spp. thrive in areas with a warm and humid weather, where the maximum Cuscuta-dependent crop yield losses also occur (Dawson et al., 1994). However, Cuscuta spp. is found in all the regions of the world. Agriculturally, the most important Cuscuta spp. are C. pentagona and C. campestris, which show an almost global distribution and have a wide host spectrum. Severe crop damage due to Cuscuta is reported for 25 crop species in 55 kingdoms (Lanini and Kogan, 2005).

To this genus belong the holoparasitic flowering plants that must take up nutrients, water, and other macromolecules from the host plants with the help of specialized absorptive organs (Seel and Jeschke, 1999; Haupt et al., 2001; Birschwilks et al., 2006, 2007).
Cuscuta vines twine around the host stems or petioles and develop haustoria-root-like structures that penetrate the host tissues and fuse with the host vascular system to uptake water and nutrients. The process begins with the enlargement of Cuscuta epidermal cells and secretion of glue-like substances containing primarily de-esterified pectins that adhere to the host (Vaughn, 2002, 2003, 2006).

It was recently shown that Cuscuta reflexa's attachment to tomato induces the host plant to synthesize arabinogalactan proteins (attAGP), which promote parasite observance (Albert et al., 2006). Following attachment, the haustorial cells elongate and penetrate the host tissues using both enzymes and mechanical pressure (Nagar et al., 1984). Individual cells of the haustoria elongate into search hyphae, which connect with the vascular bundles of the host (Birschwilks et al., 2006, 2007). On successful formation of vascular connections with the 


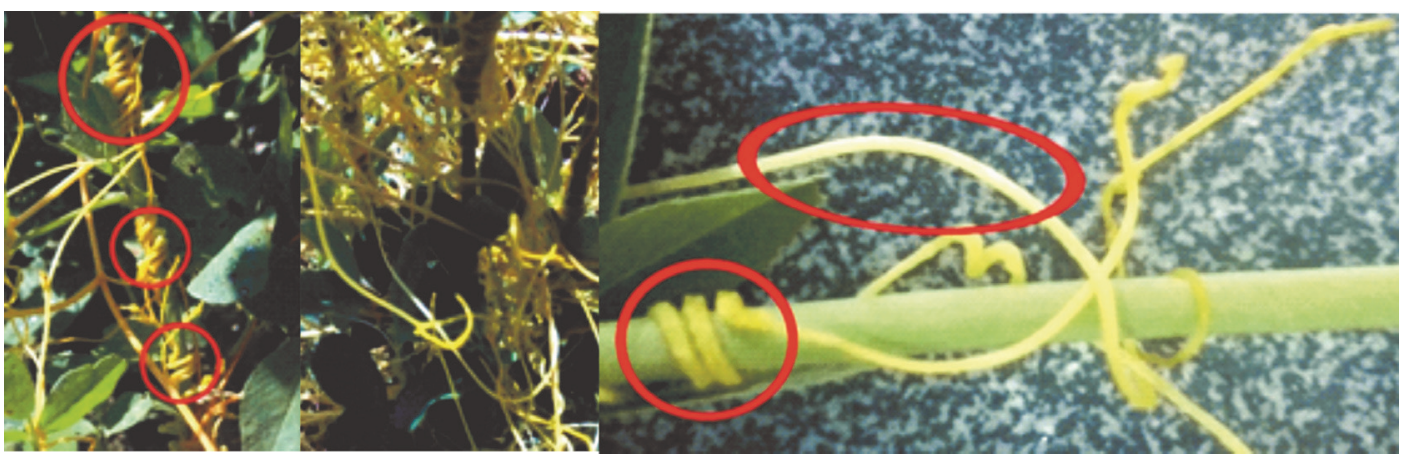

Fig. 1. Haustoria and stems of Cuscuta campestris coiled around Alfalfa stems; circles indicate regions selected for cDNA-AFLP analysis

host, Cuscuta becomes a powerful sink, uptaking water, sugars, amino acids, and other nutrients (Dawson et al., 1994; Birschwilks et al., 2007). Cuscuta are economically important pests as they damage numerous crops such as tomatoes and Alfalfa, as well as various species in natural habitats (Jiang et al., 2013).

On parasitization, dodder is intimately associated with the host plant. It can also benefit from herbicide resistance mechanisms of the host, making it difficult to attain an effective weed control without a detriment to the host (Cook et al., 2009; Nadler-Hassar et al., 2009). Agronomic and old breeding practices have additionally limited the ability to control the parasitic plant infection (Musselman et al., 2001; Mishra, 2009).

In farming zones, the control of dodder plants is very difficult due to the physiological resemblance and strong connections of the parasites with hosts. Therefore, increased understanding of the molecular mechanisms underlying the haustorium development and host attachment is vital to develop effective strategies for combating the negative effects of parasitic weeds (Aly, 2007; Alakonya et al., 2012; Jiang et al., 2013; Ichihashi et al., 2015). For the identification of the genes involved in the early stages of haustoria development, the suppression subtractive hybridization (SSH) technique was used; the genes involved in host-parasite interaction, haustorium initiation (pectin acetylesterase that plays a role in pectin modification during the infection process), oxidation of a number of substrates in young haustoria (genes encoding peroxidases), and also genes coding xyloglucan endotransglucosylase/hydrolase (XTH) that were highly and exclusively expressed at the onset of haustoria development, possibly involved in the invasive growth of the haustoria have been identified (Olsen et al., 2016).
Cuscutain (a cysteine protease from Cuscuta reflexa) playing a role in host-parasite interactions (Bleischwitz et al., 2010), genes encoding enzymes involved in cell wall modifications (Ranjan et al., 2014) taking part in haustorium development have been identified as well. Jiang et al., (2013) discovered ESTs (Expressed Sequence Tags) with sequence similarities to known plant viruses, including cryptic viruses, in the dodder sequence assemblies. They also determined that dodders are thought to have relatively robust antimicrobial defense capabilities. These data suggest that many genes of parasitic plants may be involved in attacks on the host plants and perform cell wall modifications in order to obtain nutrients and water. Our aim was to identify the genes involved in defense in dodder in its connection site with the Alfalfa host during the attachment phase.

\section{Materials and methods}

\section{Plant material}

Cuscuta campestris were propagated on a compatible host Alfalfa (Fig. 1) in a field in the campus of Ramin Agriculture and Natural University (Khozestan-Iran).

\section{Inoculation with C. campestris and collection of samples}

To create a connection zone in the host-parasite systems, about $30 \mathrm{~cm}$ long Cuscuta campestris stems were coiled around stems of 2.5-month-old Alfalfa plants. Noninfective regions of dodder stems $(25 \mathrm{~cm}$ away from host plants)and haustoria were collected separately 3 days post infection, because at this time the first visible haustoria were established. The collected samples were washed with distilled water, dried with filter paper, and then immediately frozen in liquid nitrogen and stored at $-80^{\circ} \mathrm{C}$. 
Table 1. Primer sequences, designed from sequenced transcript-derived fragments, used for qRT-PCR validation analyzes

\begin{tabular}{l|c|c|l|l}
\hline \multicolumn{1}{c}{ Primer ID } & $\begin{array}{c}\text { Size } \\
(\mathrm{nt})\end{array}$ & $\begin{array}{c}T_{a} \\
{\left[{ }^{\circ} \mathrm{C}\right]}\end{array}$ & \multicolumn{1}{|c}{ Forward primer } & \multicolumn{1}{c}{ Reverse primer } \\
\hline Actin & 100 & 57 & ATGGAAGCTGCTGGAATCCAC & TTGCTCATACGGTCAGCGATG \\
\hline ATP & 117 & 59 & CCTGGCTGTTGGGATTTC & CATTGGCAAGGTGGATGAG \\
\hline Lys & 100 & 59 & ATCACATAGAAGCATCACCTC & TGAGAGACATGATGAAGTGAAC \\
\hline
\end{tabular}

$T_{a}$ - annealing temperature

\section{RNA extraction and cDNA synthesis}

Total RNA was isolated from 100 to $200 \mathrm{mg}$ of frozen tissue material (stem and haustorium), using RNeasy Mini Kit (Qiagen, USA) according to manufacturer's instructions. Quality and quantity of isolates were analyzed on $1 \%(\mathrm{w} / \mathrm{v})$ agarose gels in $1 \mathrm{x}$ TBE buffer, using a NanoDrop spectrophotometer. Single-stranded cDNA (ss-cDNA) was synthesized with Prime Script First Strand cDNA Synthesis Kit protocol (cDNA Synthesis Kits, Takara, Japan). Double-stranded cDNA (dscDNA) was synthesized using 20- $\mu$ l first strand cDNA, RNase H ( 5 units $/ \mu \mathrm{l})$, DNA Polymerase I (10 units $/ \mu \mathrm{l})$, T4 DNA Polymerase (Thermo Scientific, USA), and $10 \mathrm{mM}$ of dNTP mix, at $15^{\circ} \mathrm{C}$ for $2 \mathrm{~h}$. The resulting dscDNA was purified using 1 volume of phenol: chloroform: isoamyl alcohol $(25: 24: 1)$ plac. The pellets were washed, dried, and dissolved in $40 \mu \mathrm{l}$ of nuclease-free water. Five microliters from ds-cDNA of each sample was analyzed on $2 \%(\mathrm{w} / \mathrm{v})$ agarose gel in $1 \times \mathrm{TBE}$ buffer.

\section{cDNA-AFLP analysis}

About 600 ng of ds-cDNA were used for the cDNAAFLP analysis. Ds-cDNA was digested for $3 \mathrm{~h}$ at $37^{\circ} \mathrm{C}$ with EcoRI, and $2 \mathrm{~h}$ at $65^{\circ} \mathrm{C}$ with TruI1 (MseI) (Thermo Scientific, USA). Then, the reaction mixtures were incubated for $15 \mathrm{~min}$ at $80^{\circ} \mathrm{C}$ to inactivate the enzymes. The digested products were ligated to EcoR1 and TruI1 dsDNA adapters by T4 DNA Ligase (Thermo Scientific, USA) for $2 \mathrm{~h}$ at $22^{\circ} \mathrm{C}$ and then incubated for $15 \mathrm{~min}$ at $65^{\circ} \mathrm{C}$. The preselective amplification mixture was prepared using $1 / 3$ volume of the digested and ligated cDNA (as template) and primers corresponding to EcoR1 and TruI1 adapters with an additional selective base (EcoRI, 5'-GACTGCGTACCAATTCA-3' and MseI, 5'-GATGAGTCCTGAGTAAC-3') for 23 cycles $\left(94^{\circ} \mathrm{C}, 30 \mathrm{~s}\right.$ for denaturation; $56^{\circ} \mathrm{C}, 60 \mathrm{~s}$ for annealing; and $72^{\circ} \mathrm{C}, 60 \mathrm{~s}$ for extension). The PCR product was diluted (30-fold) with nuclease-free water. Then, $2 \mu \mathrm{l}$ were used for PCR amplification using 8 combinations of selective $E c o$ RI and $T r u I 1$ primers with three additional nucleotides at their $3^{\prime}$-ends ( 4 primers for $\operatorname{TruI} 1+3$ (AAG and ACC) and 2 primers for $E c o \mathrm{R} 1+3$ (CAA, CAC, CAT, CAG) (Akash et al., 2013). Next, PCR was performed as follows: denaturation $5 \mathrm{~min} 94^{\circ} \mathrm{C}, 13$ cycles of $94^{\circ} \mathrm{C}$ for $30 \mathrm{~s}, 65^{\circ} \mathrm{C}$ for $30 \mathrm{~s}\left(-0.7^{\circ} \mathrm{C}\right.$, in each cycle $)$ and $72^{\circ} \mathrm{C}$ for $60 \mathrm{~s}$; then, followed by 23 cycles of $94^{\circ} \mathrm{C}$ for $30 \mathrm{~s}, 56^{\circ} \mathrm{C}$ for $30 \mathrm{~s}, 72^{\circ} \mathrm{C}$ for $60 \mathrm{~s}$, and $72^{\circ} \mathrm{C}$ for $10 \mathrm{~min}$. To each PCR product, $5 \mu$ l of DNA sequencing stop solution was added, and $9 \mu \mathrm{l}$ of each sample was separated on a $6 \%(\mathrm{w} / \mathrm{v})$ polyacrylamide gel run at $1800 \mathrm{~V}$ and $50 \mathrm{~W}$ and $45^{\circ} \mathrm{C}$ for $2 \mathrm{~h}$ (Bachem et al., 1996). Amplicons were visualized by silver staining (Bassam et al., 1991).

Bands with differences in intensities, and polymorphic transcript-derived fragments (TDFs, chosen based on a presence or absence of bands in haustorium compared with the stem) were excised from the gel with a scalpel, and placed in $50 \mu \mathrm{l}$ of nuclease-free water at $4{ }^{\circ} \mathrm{C}$ overnight and then stored at $-20^{\circ} \mathrm{C}$. About $3 \mu \mathrm{l}$ of each sample was used for reamplification in $20 \mu \mathrm{l}$ using the same set of selective primers and PCR program as used for the preamplification (annealing temperature of $56^{\circ} \mathrm{C}$ for 35 cycles). $\mathrm{PCR}$ products were resolved in a $2 \%$ $(\mathrm{w} / \mathrm{v})$ agarose gel in $1 \times \mathrm{TBE}$ buffer; each transcript was isolated and purified using the DNA gel extraction kit (Vivantis).

\section{Sequencing of TDFs}

Among the 145 fragments, 20 TDFs that differed between the haustorium and the stem from the haustorium area (connection zone with host) were sequenced at Macrogen-Korea. TDFs sequences were analyzed using BLASTx and BLASTn programs of the National 
Center for Biotechnology Information database (NCBI: http://www.ncbi.nlm.nih.gov).

\section{Real-time RT-PCR analysis}

Real-time RT-PCR analysis was performed to verify the expression levels of three selected sequences (numbered 2, 4, and 6; details are given in Table 1) with known functions in haustorium. Single-stranded cDNA was synthesized from $1 \mu \mathrm{g}$ of the total RNA (treated with RNase-free DNase) using the First-Strand cDNA Synthesis Kit (TaKaRa, Japan) following the manufacturer's instructions. Forward and reverse real-time PCR primers specific for chosen TDFs were designed using Integrated DNA Technologies database (IDT: https://eu. idtdna.com/ Primerquest/Home/Index) (Table 1). Quantitative RT-PCR (qRT-PCR) was performed using Step One Plus Real-Time PCR System by HiFi SYBR Mix Plus (Takara, Japan). The total volume of reactions were $25 \mu \mathrm{l}$, including $1 \mu \mathrm{l}(0.2 \mu \mathrm{M})$ of each primer, $2 \mu \mathrm{l} \mathrm{HiFi}$ SYBR Mix Plus, $2 \mu$ l of diluted (1/10) first strand cDNA, and $4 \mu \mathrm{l}$ nuclease-free water. PCR conditions were as follows: denaturation for $10 \mathrm{~min}$ at $95^{\circ} \mathrm{C}$, followed by 40 cycles of denaturation for $15 \mathrm{~s}$ at $95^{\circ} \mathrm{C}$, annealing for $20 \mathrm{~s}$ at $72^{\circ} \mathrm{C}$, and one more elongation step at the end for $15 \mathrm{~s}$ at $72^{\circ} \mathrm{C}$. For the determination of relative quantification of gene expression a housekeeping (Cr)-ACTIN gene was used as a reference.

\section{Results}

The stem and haustorium of dodder (connection and nonconnection regions to a host plant) were used for cDNA-AFLP transcript profiling to identify genes that were differentially regulated during the infection process.

The analyzed eight primer combinations allowed for the visualization of 439 TDFs. Per primer combination, on average, 55 TDFs were visualized as bands, from 30 to $600 \mathrm{bp}$ in size. To determine the reproducibility of these band profiles, the experiments were repeated twice (Fig. 2).

Among 439 bands obtained in the analysis, 145 bands showed significantly different expression patterns (based on their presence/absence or difference in the levels of expression) between $C$. campestris stem and haustorium. About $9.06 \%$ and $31.9 \%$ of these fragments were up- or downregulated, or present/absent, respectively (Table 2 and Fig. 3 and Fig. 4).

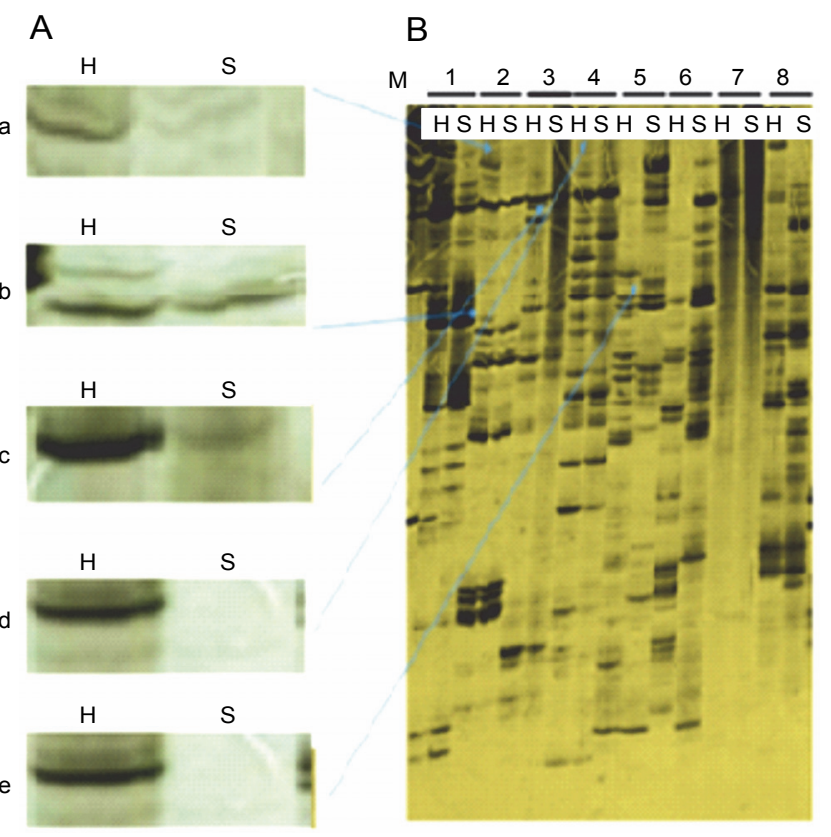

Fig. 2. A - magnification shows different expression patterns in the stem compared with that in the haustorium and some products separated and sequenced; In parts $a, b, d$, and e bands were present in the haustorium and absent in the stem of $C$. campestris, but in part c, TDF was upregulated in the haustorium and downregulated in the stem; B - silver-stained cDNA-AFLP gel showing differential expression of TDFs obtained using 8 primer combinations; numbers: 1 - EcoRI AAG-TruI1 CAA, 2 - EcoRI AAG-TruI1 CAT, 3 - EcoRI AAGTruI1 CAG, 4 - EcoRI AAG-TruI1 CAC, 5 - EcoRI ACCTruI1 CAA, 6 - EcoRI ACC-TruI1 CAT, 7 - EcoRI ACC-TruI1 CAG, and 8 - EcoRI ACC-TruI1 CAC; the samples from left to right in each combination are haustorium $(\mathrm{H})$ and stem $(\mathrm{S})$

Sequence search of these TDFs against NCBI databases was done for identification and to determine their functional classes. Sequence annotation was performed from homology search obtained using BLASTx and BLASTn programs in NCBI database (Table 3) and TDFs were classified in different functional groups. The sequenced genes were assigned to signal transduction, metabolism, respiration, and stress response groups. However, TDF8, TDF9, and TDF10 had no similar sequences in any of the databases searched. These sequences may thus represent genes that have not yet been identified and that are highly expressed in the haustorium of $C$. campestris.

To verify the data obtained from cDNA-AFLP analysis, the expression of three genes (potential hemebinding protein, lysine-specific demethylase 5A, ATP-dependent RNA helicase) were monitored by relative-quantitative RT-PCR. In all the cases, the expression profiles 
Table 2. Present, absent, and up- or downregulated TDFs detected in the stem and the haustorium of $C$. campestris obtained using eight primer combinations

\begin{tabular}{|c|c|c|c|c|c|c|}
\hline \multirow[b]{2}{*}{ Primer mix } & \multirow[b]{2}{*}{ Tissue } & \multirow{2}{*}{$\begin{array}{l}\text { Number } \\
\text { of TDFs }\end{array}$} & \multirow{2}{*}{$\begin{array}{c}\text { Different } \\
\text { polymorphism }\end{array}$} & \multirow[b]{2}{*}{ Upregulated } & \multicolumn{2}{|c|}{ Polymorphism (\%) } \\
\hline & & & & & $\begin{array}{c}\text { up- } \\
\text { or downregulated }\end{array}$ & $\begin{array}{l}\text { presence } \\
\text { or absence }\end{array}$ \\
\hline $\mathrm{AAG} / \mathrm{CAA}$ & $\begin{array}{l}\text { stem } \\
\text { haustorium }\end{array}$ & $\begin{array}{l}18 \\
27\end{array}$ & $\begin{array}{c}2 \\
16\end{array}$ & $\begin{array}{l}0 \\
0\end{array}$ & $\begin{array}{l}0 \\
0\end{array}$ & $\begin{array}{l}11.11 \\
59.26\end{array}$ \\
\hline AAG/CAT & $\begin{array}{l}\text { stem } \\
\text { haustorium }\end{array}$ & $\begin{array}{l}27 \\
11 \\
\end{array}$ & $\begin{array}{c}13 \\
3 \\
\end{array}$ & $\begin{array}{l}0 \\
0\end{array}$ & $\begin{array}{l}0 \\
0\end{array}$ & $\begin{array}{l}48.14 \\
27.27 \\
\end{array}$ \\
\hline AAG/CAG & $\begin{array}{l}\text { stem } \\
\text { haustorium }\end{array}$ & $\begin{array}{l}21 \\
19\end{array}$ & $\begin{array}{l}15 \\
10 \\
\end{array}$ & $\begin{array}{l}0 \\
0\end{array}$ & $\begin{array}{l}0 \\
0\end{array}$ & $\begin{array}{l}71.42 \\
52.36 \\
\end{array}$ \\
\hline $\mathrm{AAG} / \mathrm{CAC}$ & $\begin{array}{l}\text { stem } \\
\text { haustorium }\end{array}$ & $\begin{array}{l}32 \\
20\end{array}$ & $\begin{array}{c}21 \\
5\end{array}$ & $\begin{array}{l}0 \\
0\end{array}$ & $\begin{array}{l}0 \\
0\end{array}$ & $\begin{array}{c}65.62 \\
25\end{array}$ \\
\hline $\mathrm{ACC} / \mathrm{CAA}$ & $\begin{array}{l}\text { stem } \\
\text { haustorium }\end{array}$ & $\begin{array}{l}34 \\
48\end{array}$ & $\begin{array}{c}1 \\
12\end{array}$ & $\begin{array}{l}2 \\
5\end{array}$ & $\begin{array}{c}5.9 \\
10.41\end{array}$ & $\begin{array}{c}2.94 \\
25\end{array}$ \\
\hline ACC/CAT & $\begin{array}{l}\text { stem } \\
\text { haustorium }\end{array}$ & $\begin{array}{l}37 \\
36 \\
\end{array}$ & $\begin{array}{l}4 \\
5\end{array}$ & $\begin{array}{c}2 \\
10 \\
\end{array}$ & $\begin{array}{c}5.4 \\
27.8\end{array}$ & $\begin{array}{l}10.81 \\
13.88 \\
\end{array}$ \\
\hline $\mathrm{ACC} / \mathrm{CAG}$ & $\begin{array}{l}\text { stem } \\
\text { haustorium }\end{array}$ & $\begin{array}{l}12 \\
41\end{array}$ & $\begin{array}{c}0 \\
28\end{array}$ & $\begin{array}{l}0 \\
6\end{array}$ & 13.04 & $\begin{array}{c}0 \\
68.29\end{array}$ \\
\hline $\mathrm{ACC} / \mathrm{CAC}$ & $\begin{array}{l}\text { stem } \\
\text { haustorium }\end{array}$ & $\begin{array}{l}23 \\
33\end{array}$ & $\begin{array}{c}0 \\
10 \\
\end{array}$ & $\begin{array}{l}0 \\
0 \\
\end{array}$ & $\begin{array}{l}0 \\
0\end{array}$ & $\begin{array}{c}0 \\
30.30 \\
\end{array}$ \\
\hline \multicolumn{2}{|c|}{ Total } & 439 & 145 & 27 & 9.06 & 31.90 \\
\hline
\end{tabular}
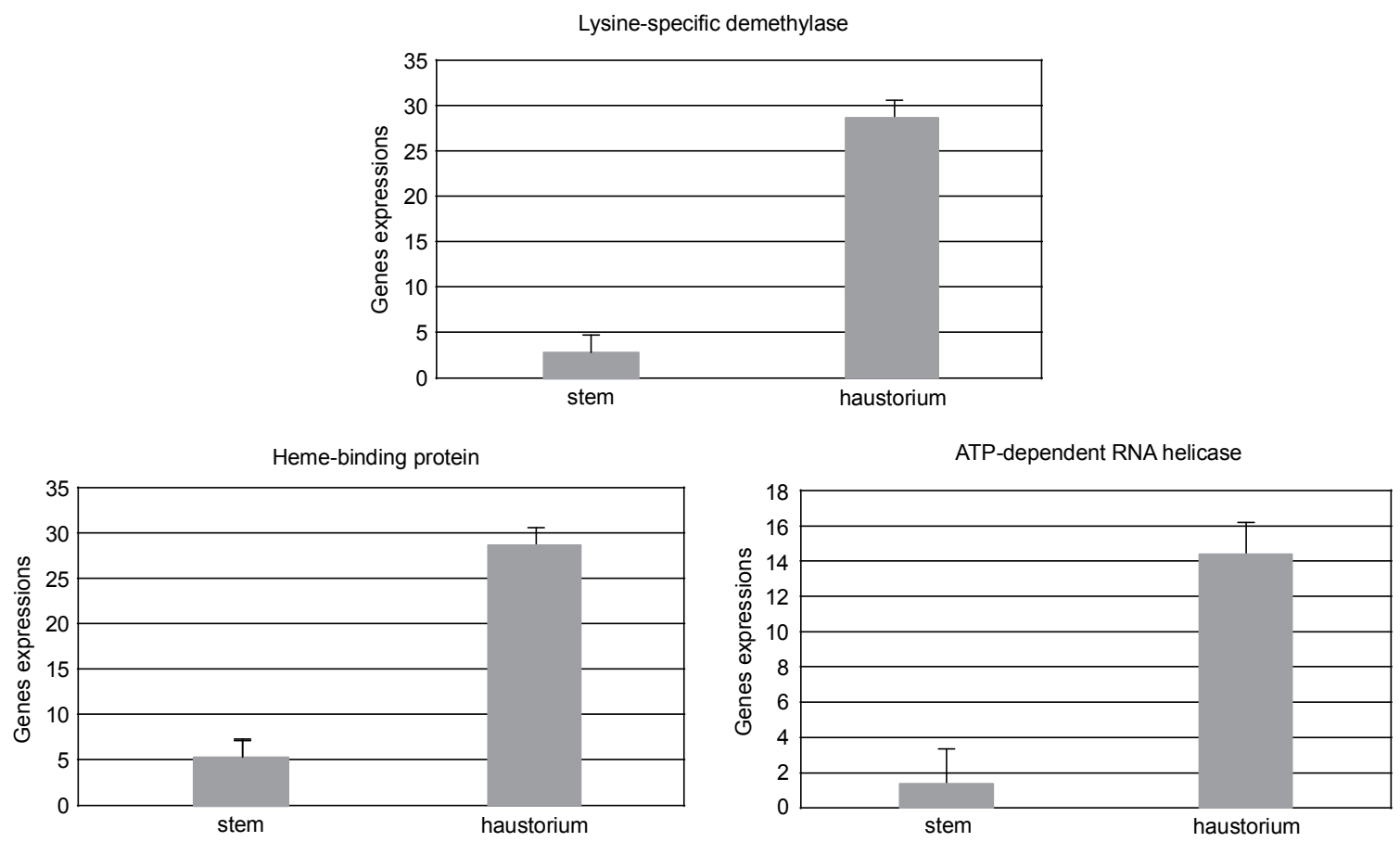

Fig. 3. Quantitative RT-PCRs validate the expression of TDFs in cDNA-AFLP analysis; expression patterns of heme-binding protein; expression patterns of lysine-specific demethylase; expression patterns of ATP-dependent RNA helicase 


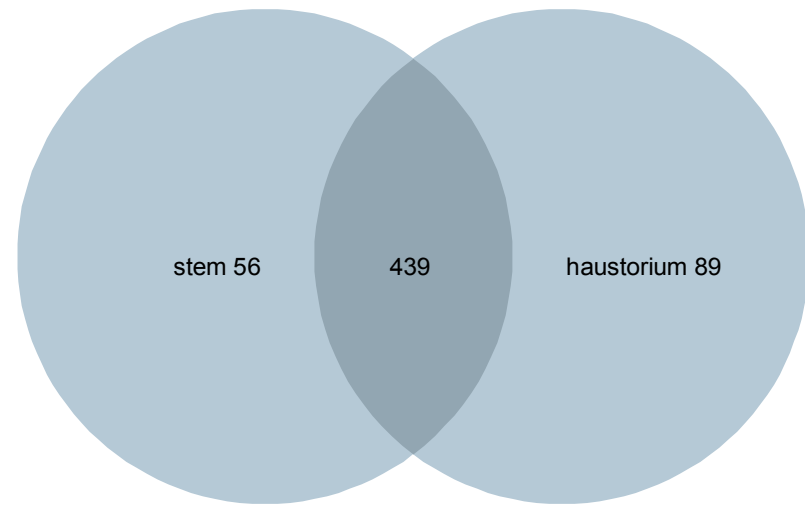

Fig. 4. Numbers of genes showing significantly different expression patterns between the stem and a haustorium of C. campestris

were consistent with the results obtained from the cDNA-AFLP analysis (Fig. 3).

High expression levels of TDFs no. 2, 4, and 6 in the haustorium compared with the dodder stems (11.48-, 11-, and 5.2-fold upregulated, respectively), indicate expression pattern correctly under the attachment conditions.

\section{Discussion}

Development of effective strategies for controlling the spread of dodder in the fields can be available only through learning more about different aspects of interactions between Cuscuta and its hosts and also about the aspects of molecular mechanisms of parasite invasion. Our findings provide new evidence supporting important roles of some genes during dodder invasion. Those genes have also been implicated in stress responses. Comparative transcriptomic analysis such as cDNAAFLP provided a valuable resource for studying host-dodder interactions in the past (Ranjan et al., 2014; Breyne and Zabeau, 2001). In our research, the highest upregulation in cDNA-AFLP analysis was observed for genes encoding for heme-binding protein, lysine-specific demethylase, and ATP-dependent RNA helicase. These data were confirmed by real-time PCR showing the overexpression of these genes in haustorium compared with the stem tissue of Cuscuta. Our data support the thesis that these genes could be involved in facilitating haustorium invasion on a host plant.

The sequence of TDF2 (upregulated in haustorium tissue compared with dodder stems) was annotated in NCBI database as DEAD-box ATP-dependent RNA helicase. DEAD-box ATP-dependent RNA helicases belong to the largest family of RNA helicases. They use energy derived from ATP hydrolysis to promote the proper folding of RNA molecules (Tanner and Linder, 2001). Evidence suggests that this candidate gene regulating RNA metabolism (Zhu et al., 2015) is also involved in a transfer of mRNAs (Itadani et al., 1994) and microRNA biogenesis (Park et al., 2002; Reinhart et al., 2002). Based on these findings, we have proposed that DEAD-box ATP-dependent RNA helicases may regulate the movement of RNAi signals through parasite bridges from host tissues into Cuscuta. Exchange of mRNAs between a parasitic plant and its host was reported earlier (Kim et al., 2014). Therefore, the overexpression of DEADbox RNA helicase in haustorium can be explained by the crucial role played in the transfer of mRNA or RNAi signals between the parasite and its host and also important roles played in regulating different defense signaling pathways against biotic and abiotic stresses ( $\mathrm{Li}$ et al., 2008). Several DEAD-box RNA helicase transcripts were identified through genome-wide expression profiling analyzes, which suggest these genes might be differentially regulated under stress conditions such as cold and chilling (Seki et al., 2002; Kreps et al., 2002; Gong et al., 2005; Kant et al., 2007). The DEAD-box RNA helicase's performance during stress conditions have not yet been fully specified or understood as a result of poor knowledge on the enzymes in plants.

TDF4 sequence, which corresponds to the potential heme-binding protein, is upregulated in haustorium. The presence of a large number of heme carrier proteins supports the hypothesis that heme is more suitable as a drought stress signal stimulating ROS detoxification under drought stress (Nagahatenna et al., 2015). It has been proposed that heme could posttranslationally activate specific transcription factors that are necessary for stress acclimation (Nagahatenna et al., 2015). Defense mechanisms may be induced by dodder parasitism in the host plants (Runyon et al., 2010). Interestingly, the parasitic plant is also under biotic stress and uses its own defense mechanisms to overcome the host's counter attack (Ranjan et al., 2014). Some stress conditions modulate heme synthesis (DeFranceschi et al., 2011); similarly to other heme-binding proteins, it may be involved in the cellular protection against heme-mediated oxidative damage to the cell (Immenschuh et al., 1999).

Nucleotide sequence of TDF6 is similar to lysinespecific demethylase 5A. Based on the real-time PCR 
Table 3. TDFs differentially expressed in the haustorium that are similar to genes encoding proteins with known functions

\begin{tabular}{|c|c|c|c|c|c|c|}
\hline $\mathrm{TDF}_{\mathrm{s}}$ & Prime name & $\begin{array}{l}\text { Size } \\
\text { (bp) }\end{array}$ & Annotation & ID & Species & E-values \\
\hline $\begin{array}{c}\text { Nucleic acid } \\
\text { metabolism } \\
2\end{array}$ & E-ACC / M-CAT & 302 & $\begin{array}{l}\text { DEAD-box ATP-dependent } \\
\text { RNA helicase }\end{array}$ & 80020935 & $\begin{array}{l}\text { Vitis } \\
\text { vinifera }\end{array}$ & $2 \mathrm{e}-60$ \\
\hline $\begin{array}{c}\text { Signal } \\
\text { transduction } \\
3\end{array}$ & E-AAG / M-CAG & 129 & $\begin{array}{l}\text { calcium-dependent protein kinase } \\
\text { (CPK5) mRNA }\end{array}$ & 80020936 & $\begin{array}{l}\text { Nicotiana } \\
\text { tabacum }\end{array}$ & $5 e-19$ \\
\hline $\begin{array}{c}\text { Photosynthesis } \\
\text { and energy } \\
4\end{array}$ & E-ACC / M-CAC & 79 & potential heme-binding protein & 80020937 & $\begin{array}{l}\text { Cuscuta } \\
\text { gronovii }\end{array}$ & $4 \mathrm{e}-23$ \\
\hline $\begin{array}{c}\text { Cell defense } \\
\text { and stress } \\
5\end{array}$ & E-AAG / M-CAA & 167 & GPI mannosyltransferase 1 & 80020938 & $\begin{array}{l}\text { Nicotiana } \\
\text { sylvestris }\end{array}$ & $3 e-18$ \\
\hline 6 & E-AAG / M-CAA & 219 & lysine-specific demethylase $5 \mathrm{~A}$ & 80020939 & $\begin{array}{c}\text { Beta } \\
\text { vulgaris }\end{array}$ & $9 \mathrm{e}-26$ \\
\hline 8 & E-AAG / M-CAT & 169 & no significant similarity & 80020940 & & \\
\hline 9 & E-AAG / M-CAT & 167 & no significant similarity & 80020942 & & \\
\hline 10 & E-AAG / M-CAG & 319 & no significant similarity & 80020943 & & \\
\hline
\end{tabular}

analysis, the expression level of lysine-specific demethylase gene increased by 11 -fold in the haustorium tissue compared with that in the stem. Methylation of lysine residues within histone tails is an important modification that contributes to an increase in gene expression levels or their repression depending on the specific residue methylated and the degree of methylation (Heightman, 2011). Therefore, lysine-specific demethylase $5 \mathrm{~A}$ plays an essential role in regulating various developmental processes (Liu et al., 2010), transcriptional regulation (Zhou et al., 2010), and plant responses to various stresses (Yuan et al., 2013).

TDF3, which corresponds to calcium-dependent protein kinase, is upregulated in haustorium. Calcium levels, as molecular signaling molecules, are increased by a diverse physiological stimuli and stresses. Calciumdependent protein kinases are plant proteins that directly bind calcium ions and therefore play important roles as $\mathrm{Ca}^{2+}$ sensor proteins in transducing differential $\mathrm{Ca}^{2+}$ signatures, that are triggered by effectors and activating complex downstream responses (Gao et al., 2014). They are involved in metabolism, osmosis, hormone response, and stress signaling pathways (Valmonte et al., 2014).

The sequence of TDF2 was annotated as glycosylphosphatidylinositol mannosyltransferase 1 (GPI-MTs) that is essential for glycosylphosphatidylinositol (GPI) biosynthesis, that GPI-anchored proteins serve essential functions as cell adhesion molecules (CAMs), hydrolytic enzymes, and are also attached to cell-wall glycoproteins compounds, for example attached to Arabinogalactan proteins (AGPs) that belong to the hydroxyproline-rich superfamily of glycoproteins and are known to be involved in many biological processes like cell division, cell elongation, and cell death (Spree et al., 1994; Gao et al., 1999; Van Hengel et al., 2002; Gillmor et al., 2005). Cell walls play an important role in plant protection against stress conditions (Striberny and Krause, 2015). Various observations support the hypothesis that through connections formed between dodder and the host plant, transfer of nutrients, water, and even proteins, viruses, or RNAs into the parasitic plants or in a bidirectional manner occurs (Haupt et al., 2001; Hibberd et al., 1998; Albert at al., 2006; Fürst et al., 2016).

\section{Conclusions}

Based on our findings, we hypothesize that defense responses were elicited in dodder to overcome host defense responses in connection zones. Cuscuta parasites may encounter miRNA signaling molecules that are 
generated in stressed plants (Stefanovic et al., 2002). We observed that the migration of signals from the host to the parasitic plant induced the expression of specific genes to overcome plant defense responses. In our study, several genes with different functions were identified, such as ATP-dependent RNA helicase, glycosylphosphatidylinositol mannosyltransferase 1 (GPI-MTs), calcium-dependent protein kinase, and heme-binding protein. These findings could help further knowledge on the interaction between the host and the parasite.

\section{References}

Alakonya A., Kumar R., Koenig D., Kimura S., Townsley B., Runo S., Machuka J. (2012) Interspecific RNA interference of SHOOT MERISTEMLESS-like disrupts Cuscuta pentagona plant parasitism. Plant Cell 24(7): 3153-3166.

Albert M., Belastegui-Macadam X., Kaldenhoff R. (2006) An attack of the plant parasite Cuscuta reflexa induces the expression of attAGP, an attachment protein of the host tomato. Plant J. 48(4): 548-556.

Aly R. (2007) Conventional and biotechnological approaches for control of parasitic weeds. In Vitro Cell. Develop. Biol.-Plant 43(4): 304-317.

Bachem C.W., Hoeven R.S., Bruijn S.M., Vreugdenhil D., Zabeau M., Visser R.G. (1996) Visualization of differential gene expression using a novel method of RNA fingerprinting based on AFLP: analysis of gene expression during potato tuber development. Plant J. 9(5): 745-753.

Bassam B.J., Caetano-Anollés G., Gresshoff P.M. (1991) Fast and sensitive silver staining of DNA in polyacrylamide gels. Anal. Biochem. 196: 80-83.

Birschwilks M., Haupt S., Hofius D., Neumann S. (2006) Transfer of phloem-mobile substances from the host plants to the holoparasite Cuscuta sp. J. Exp. Bot. 57: 911-921.

Birschwilks M., Sauer N., Scheel D., Neumann S. (2007) Arabidopsis thaliana is a susceptible host plant for the holoparasite Cuscuta spec. Planta 226(5): 1231-1241.

Bleischwitz M., Albert M., Fuchsbauer H.L., Kaldenhoff R. (2010) Significance of Cuscutain, a cysteine protease from Cuscuta reflexa, in host-parasite interactions. BMC Plant Biol. 10(1): 1.

Breyne P., Zabeau M. (2001) Genome-wide expression analysis of plant cell cycle modulated genes. Curr. Opin. Plant Biol. 4: 136-142.

Cook J.C., Charudattan R., Zimmerman T.W., Rosskopf E.N., Stall W.M., MacDonald G.E. (2009) Effects of Alternaria destruens, glyphosate, and ammonium sulfate individually and integrated for control of dodder (Cuscuta pentagona). Weed Technol. 23(4): 550-555.

Dawson J.H., Musselman L.J., Wolswinkel P., Dorr I. (1994) Biology and control of Cuscuta. Rev. Weed Sci. 6: 265-317.

De Franceschi L., Bertoldi M., De Falco L., Franco S.S., Ronzoni L., Turrini F., Iolascon A. (2011) Oxidative stress modulates heme synthesis and induces peroxiredoxin- 2 as a novel cytoprotective response in $\beta$ thalassemic erythropoiesis. Haematologica 96(11): 1595-1604.

Fürst U., Hegenauer V., Kaiser B., Körner M., Welz M., Albert M. (2016) Parasitic Cuscuta factor (s) and the detection by tomato initiates plant defense. Commun. Integr. Biol. 9(6): e1244590.

Gao M., Showalter A.M. (1999) Yariv reagent treatment induces programmed cell death in Arabidopsis cell cultures and implicates arabinogalactan protein involvement. Plant J. 19(3): 321-331.

Gao X., Cox Jr. K.L., He P. (2014) Functions of calcium-dependent protein kinases in plant innate immunity. Plants 3(1): 160-176.

Gillmor C.S., Lukowitz W., Brininstool G., Sedbrook J.C., Hamann T., Poindexter P., Somerville C. (2005) Glycosylphosphatidylinositol-anchored proteins are required for cell wall synthesis and morphogenesis in Arabidopsis. Plant Cell 17(4): 1128-1140.

Gong Z., Dong C.H., Lee H., Zhu J., Xiong L., Gong D., Zhu J.K. (2005) A DEAD box RNA helicase is essential for $m R N A$ export and important for development and stress responses in Arabidopsis. Plant Cell 17(1): 256-267.

Haupt S., Oparka K.J., Sauer N., Neumann S. (2001) Macromolecular trafficking between Nicotianatabacum and the holoparasite Cuscuta reflexa. J. Exp. Bot. 52(354): 173-177.

Heightman T.D. (2011) Chemical biology of lysine demethylases. Curr. Chem. Genom. Translat. Med. 5(suppl. 1): 62-71.

Hibberd J.M., Bungard R.A., Press M.C., Jeschke W.D., Scholes J.D., Quick W.P. (1998) Localization of photosynthetic metabolism in the parasitic angiosperm Cuscuta reflexa. Planta 205(4): 506-513.

Holm L. (1997) World weeds: natural histories and distribution. John Wiley \& Sons.

Ichihashi Y., Mutuku J.M., Yoshida S., Shirasu K. (2015) Transcriptomics exposes the uniqueness of parasitic plants. Brief. Funct. Genomics 14(4): 275-282.

Immenschuh S., Stritzke J., Iwahara S.I., Ramadori G. (1999) $U$ p regulation of heme binding protein 23 (HBP23) gene expression by lipopolysaccharide is mediated via a nitric oxide dependent signaling pathway in rat Kupffer cells. Hepatology 30(1): 118-127.

Itadani H., Sugita M., Sugiura M. (1994) Structure and expression of a cDNA encoding an RNA helicase-like protein in tobacco. Plant Mol. Biol. 24(1): 249-252.

Jiang L., Wijeratne A.J., Wijeratne S., Fraga M., Meulia T., Doohan D., Qu F. (2013) Profiling mRNAs of two Cuscuta species reveals possible candidate transcripts shared by parasitic plants. PloS One, 8(11): e81389.

Kant P., Kant S., Gordon M., Shaked R., Barak S. (2007) STRS1 and STRS2, two DEAD-box RNA helicases that attenuate Arabidopsis responses to multiple abiotic stresses. Plant Physiol. 145(3): 814-830.

Kim G., LeBlanc M.L., Wafula E.K., Westwood J.H. (2014) Genomic-scale exchange of mRNA between a parasitic plant and its hosts. Science 345(6198): 808-811. 
Kreps J.A., Wu Y., Chang H.S., Zhu T., Wang X., Harper J.F. (2002) Transcriptome changes for Arabidopsis in res ponse to salt, osmotic, and cold stress. Plant Physiol. 130(4): 2129-2141.

Lanini W.T., Kogan M. (2005) Biology and management of Cuscuta in crops. Cien. Inv. Agr. 32(3): 127-141.

Li D., Liu H., Zhang H., Wang X., Song F. (2008) OsBIRH1, a DEAD-box RNA helicase with functions in modulating defence responses against pathogen infection and oxidative stress. J. Exp. Bot. 59(8): 2133-2146.

Liu C., Lu F., Cui X., Cao X. (2010) Histone methylation in higher plants. Ann. Rev. Plant Biol. 61: 395-420.

Mishra J.S. (2009) Biology and management of Cuscuta species. Indian J. Weed Sci. 41(1-2): 1-11.

Musselman L.J., Yoder J.I., Westwood J.H. (2001) Parasitic plants major problem to food crops. Science 293: 1434.

Nadler Hassar T., Shaner D.L., Nissen S., Westra P., Rubin B. (2009) Are herbicide resistant crops the answer to controlling Cuscuta. Pest Manag. Sci. 65(7): 811-816.

Nagahatenna Dilrukshi S.K., Langridge P., Whitford R. (2015) Tetrapyrrole based drought stress signalling. Plant Biotechnol. J. 13(4): 447-459.

Nagar R., Singh M., Sanwal G.G. (1984) Cell wall degrading enzymes in Cuscuta reflexa and its hosts. J. Exp. Bot. 35(8): 1104-1112.

Olsen S., Striberny B., Hollmann J., Schwacke R., Popper Z., Krause K. (2016) Getting ready for host invasion: elevated expression and action of xyloglucan endotransglucosylases/hydrolases in developing haustoria of the holoparasitic angiosperm Cuscuta. J. Exp. Bot. 67(3): 695-708.

Park W., Li J., Song R., Messing J., Chen X. (2002) CARPELFACTORY, a Dicer homolog, and HEN1, a novel protein, act inmicroRNA metabolism in Arabidopsis thaliana. Curr. Biol. 12: 1484-1495.

Ranjan A., Ichihashi Y., Farhi M., Zumstein K., Townsley B., David-Schwartz R., Sinha N.R. (2014) De novo assembly and characterization of the transcriptome of the parasitic weed dodder identifies genes associated with plant parasitism. Plant Physiol. 166(3): 1186-1199.

Reinhart B.J., Weinstein E.G., Rhoades M.W., Bartel B., Bartel D.P. (2002) MicroRNAs in plants. Genes Develop. 16: 1616-1626.

Runyon J.B., Mescher M.C., Felton G.W., De Moraes C.M. (2010) Parasitism by Cuscuta pentagona sequentially induces JA and SA defence pathways in tomato. Plant Cell Environ. 33(2): 290-303.

Seel W.E., Jeschke W.D. (1999) Simultaneous collection of xylem sap from Rhinanthus minor and the hosts Hordeum and Trifolium: hydraulic properties, xylem sap composition and effects of attachment. New Phytolog. 143(2): 281-298.
Spree M.D., Nothnagel E.A. (1994) Effects of Yariv phenylglycosides onRosa cell suspensions: evidence for the involvement of arabinogalactan-proteins in cell proliferation. Planta 193(4): 542-550.

Seki M., Narusaka M., Ishida J., Nanjo T., Fujita M., Oono Y., Satou M. (2002) Monitoring the expression profiles of 7000 Arabidopsis genes under drought, cold and high salinity stresses using a full length cDNA microarray. Plant J. 31(3): 279-292.

Stefanovic S., Krueger L., Olmstead R.G. (2002) Monophyly of the Convolvulaceae and circumscription of their major lineages based on DNA sequences of multiple chloroplast loci. Amer. J. Bot. 89(9): 1510-1522.

Striberny B., Krause K. (2015) Cell wall glycoproteins at interaction sites between parasitic giant dodder (Cuscuta reflexa) and its host Pelargonium zonale. Plant Signal. Behavior 10(11): e1086858.

Tanner N.K., Linder P. (2001) DEXD/H box RNA helicases: from generic motors to specific dissociation functions. Mol. Cell. 8(2): 251-262.

Valmonte G.R., Arthur K., Higgins C.M., MacDiarmid R.M. (2014) Calcium-dependent protein kinases in plants: evolution, expression and function. Plant Cell Physiol. 55(3): 551-569.

Vaughn K.C. (2003) Dodder hyphae invade the host: a structural and immune cytochemical characterization. Protoplasma 220: 189-200.

Vaughn K.C. (2002) Attachment of the parasitic weed dodder to the host. Protoplasma 219(3-4): 227-237.

Vaughn K. C. (2006) Conversion of the searching hyphae of dodder into xylic and phloic hyphae: a cytochemical and immunocytochemical investigation. Intern. J. Plant Sci. 167(6): 1099-1114.

Yuan L., Liu X., Luo M., Yang S., Wu K. (2013) Involvement of histone modifications in plant abiotic stress responses. J. Integr. Plant Biol. 55(10): 892-901.

Van Hengel A.J., Roberts K. (2002) Fucosylated arabinogalactan proteins are required for full root cell elongation in Arabidopsis. Plant J. 32(1): 105-113.

Zhou D.X., Hu Y. (2010) Regulatory function of histone modifications in controlling rice gene expression and plant growth. Rice Sci. J. 3(2-3): 103-111.

Zhu M., Chen G., Dong T., Wang L., Zhang J., Zhao Z., Hu Z. (2015) SIDEAD31, a putative DEAD-Box RNA helicase gene, regulates salt and drought tolerance and stressrelated genes in tomato. PloS One 10(8): e0133849. 